\title{
Multiple criteria decision analysis (MCDA): A tool to support sustainable management of groundwater resources in South Africa
}

\author{
Kevin Pietersen \\ Water Research Commission, Private Bag X03, Gezina, 0031, South Africa
}

\begin{abstract}
The National Water Act (NWA) of 1998 has been promulgated in South Africa to support the attainment of sustainable water resource use. Before the Act was promulgated, landowners were entitled to unlimited groundwater use. The Act rectified this anomaly; however, the practical application of sustainable development concepts in groundwater resource management will be complex. A multiple criteria decision analysis (MCDA) approach was used to identify critical alternative courses of action and to develop a decision-making framework for sustainable groundwater management. Through applying the decision model described in this paper a number of strategies have been proposed which are aligned to the legislative requirements of the NWA.
\end{abstract}

Keywords: groundwater management, multiple criteria decision analysis (MCDA), value function methods, decision model

\section{Introduction}

South African water legislation considers groundwater as a national resource to be managed in a sustainable manner. The Water Services Act and National Water Act (DWAF, 1997; DWAF, 1998) provide the framework for delivery of water services while also providing a combination of legal obligations, rights, responsibilities and constraints for the sustainable development and management of water resources in South Africa.

The National Water Act (NWA) furthermore provides the framework for the attainment of integrated water resource management (IWRM) principles. The Act recognises the unity of the water cycle, and the interdependency of all its elements, both in terms of quantity and quality. There is further recognition that the protection of water resources falls within a broader framework of integrated environmental management. The requirements of the NWA represent a challenge to groundwater resource managers at an operational level. Before the Act was promulgated, landowners were entitled to unlimited use of groundwater resources.

The focus of groundwater management in South Africa, for the foreseeable future, will be on equitable allocation for economic development, maintaining resource integrity and meeting basic human needs. The challenge is to implement these principles in reality. Management strategies will be needed to address the unique characteristics and roles of groundwater, while at the same time preserving the concept of a common resource, in the context of both continuity within the hydrological cycle and national ownership of the resource.

+27 12330 9027; fax: +2712 3312565

e-mail: kevinp@wrc.org.za

Received 16 September 2005; accepted in revised form 30 January 2006.

\section{Groundwater management}

The practical application of sustainable development concepts in groundwater resource management remains one of the greatest challenges. Fortunately, a number of authors have begun to examine the concept of sustainable groundwater management (Braune, 2003; Morris et al., 2003; Alley and Leake, 2004; Pietersen, 2004; Maimone, 2004 and Kalf and Woolley, 2005).

Morris et al. (2003) argue that the conventional approaches to groundwater management in developing countries must be reassessed as these systems presuppose the existence of institutional, legal and technical preliminaries that are simply not in place. A groundwater management approach is advocated by Morris et al. (2003) who propose a more holistic approach to sustainability in which coping strategies as well as technical measures form part of the groundwater problem-solving process. Alley and Leake (2004) have a similar view, stating that a key challenge for sustained use of groundwater resources is to frame the hydrological applications of various alternative development strategies in such a way that their long-term implications can be properly evaluated. Each hydrological system and development situation is unique and requires an analysis adjusted to the nature of the water issues faced (Alley and Leake, 2004). Maimone (2004) introduced a number of considerations that must be addressed in defining sustainable yield of an aquifer system. These include consideration for the hydrological system, the concerns and needs of the inhabitants, the potential impacts to groundwater quality, and environmental side effects (Maimone, 2004).

As a result of the above reassessment of the problem of sustainable groundwater management, methodologies are required that facilitate a more holistic approach to sustainability in which coping strategies as well as technical measures form part of the groundwater problem-solving process. This is supported by research that suggests that strategies that build on existing trends within society or help populations to adapt may be effective as strategies that attempt to manage the groundwater resource base 


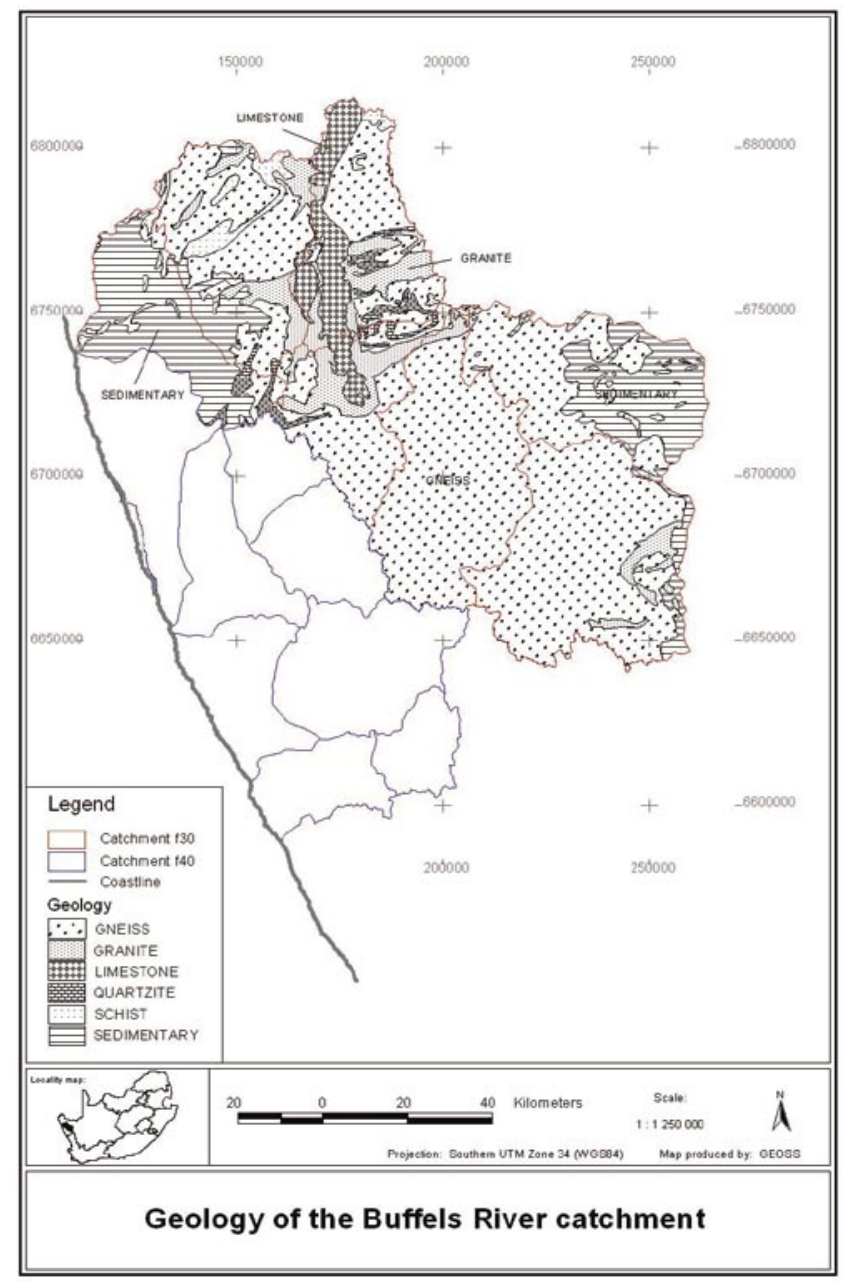

Figure 1

Locality and geology (major lithological units) of the study area in the north-western parts of South Africa (Titus et al., 2002)

directly (FAO, 2003). Further, research to clarify existing coping mechanisms and to identify or test the viability of adaptive strategies could present a major starting point for an initiative to rethink groundwater management (FAO, 2003).

This paper is based on research conducted by Pietersen (2004). The main emphasis was on investigating the applicability of MCDA as a tool for groundwater management decision making in South Africa (exemplified through a case study example in the Namaqualand region of South Africa).

\section{The Namaqualand study area}

The study region (Fig. 1) has an area of $47700 \mathrm{~km}^{2}$ and an estimated population of 60000 . Mining is the main contributor to the economy of the region. The poverty levels are high, as is unemployment (Younge, 2002). This is because the region has relied heavily on non-renewable resources that are now becoming exhausted (Odendaal, 2001). The Namakwa District Municipality consists of 14 small urban settlements, 6 communal areas, large areas of commercial farm-land and mining company property. The 6 communal areas are Richtersveld, Steinkopf, Leliefontein, Komaggas, Concordia and Pella. Livestock farming is the predominant agricultural activity in the communal areas.

The aquifer systems are mostly associated with structural features in Namaqualand. The Water Research Commission
(WRC) has supported a number of research projects in the region (Titus et al. (2002); Adams et al. (2004) and Friese et al. (2005)). On a local scale two aquifer systems exist, viz. a weathered zone or regolith aquifer underlain by a fractured crystalline aquifer (Friese et al., 2005). Groundwater flow and storage in these aquifers are inherently complex, partly because of the heterogeneity associated with the presence of fractures. The depth of the weathering extends to 54 to $60 \mathrm{~m}$ below the surface for both the metasediments and the gneissic rocks (Titus et al., 2000). Differential weathering occurs throughout the rock mass and is also observed on fracture/joint planes (Friese et al., 2005) Groundwater flow in Namaqualand is a function of complex topographic and hydrogeological environments with multiple flow systems (Titus, 2003). Titus et al. (2002) recognised shallow circulating and deeper, slower circulating groundwater systems in the Namaqualand Groundwater Region. The shallow flow system (also known as the active system) occurs within the regolith. The deeper and slower flow system (also known as the passive system) occurs within the lowest zone of the regolith and the top of the bedrock. The shallow circulating and relatively young (i.e. active) groundwater flow systems occur particularly in the higher-lying, higher-rainfall regions which are characterised by dynamic, active recharge with rapid through-flow rates (Titus et al., 2002). Perennial springs are expressions of such shallow flow systems. The deeper circulating groundwater probably experiences insignificant recharge under present climatic conditions (Titus et al., 2002).

As a result, the arid nature and groundwater characteristics of the region mean that communities are confronted with water quantity and quality issues. Coupled with the social context the people living in the region face the following livelihood challenges (as they relate to water):

- A dependency paradigm, created through the adoption of inappropriate technologies (a scenario typical in developing communities)

- The burden placed on women to perform the daily chores and tasks in order to provide subsistence to households

- Health risks (microbiological and chemical) associated with poor quality groundwater (natural and anthropogenic) and inadequate sanitation systems

- Centralised decision-making which often does not take account of community dynamics and processes

- The challenge to produce sufficient food in an environment of extreme climatic and water resource variability (mostly drought conditions)

- The degradation of the natural environment resulting in flood problems in periods of high rainfall

- Policies that focus on basic needs rather than production (livelihood) requirements (supply approach rather than a demand driven approach)

- The low population densities, making reticulated water systems excessively costly.

In the absence of surface water, the only water supply options to communities are groundwater, predominantly located in crystalline metamorphic and igneous rocks. To address the issues above will require an integrated decision-making framework that incorporates technical and social considerations.

The development of a decision-making framework for addressing wide-ranging technical and socio-economic issues will greatly assist in promoting sustainable development and effective use of groundwater resources in the region. The decision maker is often confronted, and in some cases overwhelmed, with conflicting needs and supporting information when faced 
with having to decide on how best to use limited resources in implementing water service programmes. A set of approaches is required that will synthesise this information in a coherent framework and will allow the decision maker to identify the critical pathways or activities in dealing with a complex decision problem. A multiple criteria decision analysis (MCDA) approach would be most appropriate for addressing the multiple management objectives within the context of a decision support framework for groundwater management in arid zones.

\section{Multiple criteria decision analysis (MCDA)}

MCDA is the general field of study which includes decision making in the presence of two or more conflicting objectives and/or decision analysis processes involving two or more attributes (Tecle and Duckstein, 1994). The general objective of MCDA is to assist a decision maker or a group of decision makers to choose the best alternative from a range of alternatives in an environment of conflicting and competing criteria. In recent years, several methods have been proposed to deal with MCDA problems. These are (Belton and Stewart, 2002):

- Value function methods: These methods synthesise assessments of the performance of alternatives against individual criteria, together with inter-criteria information reflecting the relative importance of the different criteria, to give an overall evaluation of each alternative indicative of the decision makers' preference.

- Goal and reference point methods: The decision maker specifies some goals to be achieved; if they are achieved the decision maker is assumed to be satisfied; if not the method seeks to get as "close as possible" to the goals.

- Outranking methods: These methods attempt pair-wise or global comparison among alternatives. An alternative $\boldsymbol{a}$ is said to outrank another alternative $\boldsymbol{b}$ if, taking into account all the available information regarding the problem and the decision maker's preferences, there is a strong enough argument to support a conclusion that $\boldsymbol{a}$ is at least as good as $\boldsymbol{b}$ and no strong argument to the contrary.

MCDA methods differ, however, in the way the idea of multiple criteria is considered, the application and computation of weights, the mathematical algorithm utilised, the model to describe the system of preferences of the individual facing decision-making, the level of uncertainty embedded in the data set and the ability for stakeholders to participate in the process (De Montis et al., 2000). The MCDA technique selected will typically need to (De Montis et al., 2000):

- Deal with complex situations (criteria), consider different scales and aspects (geographical scales, micro-macro-link), social/technical issues and type of data (uncertainties)

- Involve more than one decision maker (stakeholder participation, actors, communication, and transparency)

- Inform stakeholders in order to increase their knowledge and change their opinion and behaviour (problem structuring, tool for learning, transparency)

Value function methods are some of the more widely applied MCDA methods and have benefited from the long-standing interests of psychologists, engineers and management scientists who have been nurtured through a continuing awareness of behavioural and social issues as well as the underlying theory (Belton and Stewart, 2002). The methods are able to deal with complex issues, can accommodate the involvement of multiple stakeholders and allow processes to be facilitative and transparent (Pietersen, 2004), as are required in typical groundwater management decision-making scenarios. Value function methods can assist in the problem formulation phase and in informing stakeholders about the decision processes. The major characteristics of typical groundwater management decisionmaking scenarios are the existence of considerable uncertainty, the potential for irreversible outcomes, the involvement of multiple decision makers and the likelihood of having conflicting objectives (Hajkowicz et al., 2000).

The value function method selected for this study provides decision support by interval assessments. Dealing with uncertainties related to data and preferential judgments is an essential part of any realistic decision making situation (Lindstedt et al., 2000). In those situations, it is possible to use imprecise value statements such as intervals when judging objective weights' and attributes' performance levels (Dietrich and Hämäläinen, 2002). Mustajoki et al. (2004) studied the use of intervals in simple multiple attribute rating technique (SMART) and SWING weighting ratio estimation methods. This is known as interval SMART/SWING. Extensive theoretical and software development for these methods was done at the Systems Analysis Laboratory, Helsinki, University of Technology (Mustajoki and Hämäläinen, 1999; Pöyhonen and Hämäläinen, 2001; Hämäläinen and Mäntysaari, 2001).

\section{Adoption of a multiple criteria decision analysis (MCDA) approach to sustainable groundwater management}

The following methodology was followed in developing the decision model for groundwater in Namaqualand (Pietersen, 2004):

- Problem structuring: Necessary steps are to understand the social and resource context; to review the decision context; to identify the objectives; and to generate and identify the decision alternatives.

- Decompose and model the problem: This process involves method selection, value tree construction and value function analysis.

- Application of the decision model.

\section{Problem structuring}

The decision problem consisted of selecting the most appropriate coping strategies and management interventions to include in a holistic approach to sustainable development of the groundwater resources of the region (Titus et al., 2002; Pietersen, 2004). The coping strategies and management interventions were developed through (Pietersen, 2004):

- Field investigations to collect data in order to understand the physical conditions of the groundwater system. The case study consisted of detailed investigations (hydrological, hydrogeological and hydrochemical data collection, interpretation and analysis).

- Pilot studies and workshops in affected communities to consult and gain an understanding of issues related to water services. The methods used in the Buffels River case study example consisted of questionnaires and field data collected using participative techniques, semi-structured interviews and in-depth focus discussions among various communities in the region.

- Consultations with decision makers, implementing agents and water resource managers at local, provincial and national level. This was done in the case study, through interviews and interactions at various forums. 
A subset of the list of objectives is given for illustration purposes in Table 1.

It is accepted that the objectives and associated measures that were identified in Titus et al. (2002) were too numerous and cumbersome for practical, economic implementation.

\begin{tabular}{|c|c|}
\hline \multicolumn{2}{|c|}{$\begin{array}{c}\text { TABLE } 1 \\
\text { Subset of objectives and associated measures for } \\
\text { sustainable rural livelihoods (Titus et al., 2002) }\end{array}$} \\
\hline Issue & Objectives and associated measures \\
\hline $\begin{array}{l}\text { Adverse } \\
\text { climatic } \\
\text { condition }\end{array}$ & $\begin{array}{l}\text { - Implement artificial recharge schemes to sup- } \\
\text { plement poorly naturally recharged groundwa- } \\
\text { ter systems when surface water resources are in } \\
\text { excess. } \\
\text { - Continue conjunctive water use of groundwater } \\
\text { and surface water resources. } \\
\text { - Implement water harvesting by storing roof- } \\
\text { runoff in rainfall tanks and the construction of } \\
\text { structures to channel overland flow to reser- } \\
\text { voirs. } \\
\text { - Consider fog harvesting in coastal and moun- } \\
\text { tainous regions. } \\
\text { - Implement water harvesting during exceptional } \\
\text { rainfall events through retention walls in streams } \\
\text { to enhance infiltration. } \\
\text { - Undertake proper maintenance of reservoir sys- } \\
\text { tems/pipelines to reduce leakage and evapora- } \\
\text { tion. Closed tanks, instead of open dams, located } \\
\text { in proximity of the boreholes may also reduce } \\
\text { evaporation. } \\
\text { - Manage the resource properly through water } \\
\text { level and water quality monitoring to charac- } \\
\text { terise the response of the aquifer system with } \\
\text { regard to adverse climatic conditions. }\end{array}$ \\
\hline
\end{tabular}

The challenge was to establish the critical path for key intervention measures serving the high-level objectives associated with sustainable livelihoods. The list of interventions was rationalised and shortened by consolidating overlapping measures and discarding those considered of lesser importance. The result is a similarly categorised list of potential activities (key measures) designed to promote the achievement of sustainable livelihoods (Table 2). If, as is usually the case, resources (human and financial) are limited, it would be crucial to decide which of these activities (or combination of activities) should be selected and pursued in order to bring about the best possible result in terms of achieving sustainable rural livelihoods. For this reason, the possible activities may be considered as, and termed, decision alternatives. Ideally, the decision alternatives should be generated and tested in a workshop format prior to the commencement of the decision-making process. An MCDA approach will be used to throw more light on the interventions required.

\section{Decompose and model the problem}

As stated above, a value function MCDA method, using interval assessment, was chosen to decompose and model the problem. This method provides an interactive technique for the decision maker to interrogate various decision alternatives. It accommodates informational uncertainty, a characteristic of water resource management issues. In this case, the technique was utilised by a single decision maker.

The task was to develop a decision-making framework, considering the importance and interrelationship of various attributes associated with various decision alternatives identified in Table 2. An attribute is a quantitative measure of performance linked to a particular criterion, according to which an alternative measure or course of action is to be evaluated (Belton and Stewart, 2002). The software Workbench for Interactive

\begin{tabular}{|c|c|}
\hline \multicolumn{2}{|r|}{$\begin{array}{c}\text { TABLE } 2 \\
\text { Decision alternatives for groundwater management in Namaqualand (Pietersen, 2004) }\end{array}$} \\
\hline Issues & Decision alternatives \\
\hline Cost recovery & $\begin{array}{l}\text { Involve communities in the selection of technology and developing the cost recovery system } \\
\text { Facilitate technology selection and tariff setting at local government level }\end{array}$ \\
\hline $\begin{array}{l}\text { Aquifer manage- } \\
\text { ment }\end{array}$ & $\begin{array}{l}\text { Conduct water demand assessments; develop community participation and management systems } \\
\text { Undertake technical assessments of the aquifer systems and institute aquifer monitoring systems }\end{array}$ \\
\hline Aquifer protection & $\begin{array}{l}\text { Develop protection zones around identified environmental assets } \\
\text { Compile an inventory of contamination sources } \\
\text { Determine groundwater contribution to base flow } \\
\text { Develop borehole protection zones from contamination sources }\end{array}$ \\
\hline Aquifer assessment & $\begin{array}{l}\text { Undertake a detailed geological and geomorphological review of region (including geodynamics and struc- } \\
\text { tural geology) } \\
\text { Characterise aquifers at regional scale (regional groundwater flow model) } \\
\text { Characterise aquifers at local scale (e.g. proper pump testing analysis) }\end{array}$ \\
\hline $\begin{array}{l}\text { Coping with } \\
\text { climate variability } \\
\text { and change }\end{array}$ & $\begin{array}{l}\text { Use outputs of a suitable predictive model available to inform decision makers about spatial and temporal } \\
\text { climate variability and change } \\
\text { Undertake a water demand analysis to indicate trends and resource availability }\end{array}$ \\
\hline $\begin{array}{l}\text { Adverse climatic } \\
\text { conditions }\end{array}$ & $\begin{array}{l}\text { Implement water enhancement strategies such as artificial recharge, water harvesting and fog harvesting } \\
\text { Reduce water loss and leakage through measures such as maintenance of water distribution systems } \\
\text { Practise water level and water quality monitoring in order to characterise the response of the aquifer system } \\
\text { with regard to adverse climatic conditions and to adapt water supply in accordance with such conditions }\end{array}$ \\
\hline $\begin{array}{l}\text { Ensuring operation } \\
\text { and maintenance } \\
\text { skills base }\end{array}$ & $\begin{array}{l}\text { Ensure training and retention of necessary skills (including gender considerations) for the operation and } \\
\text { maintenance of the water services system at community level } \\
\text { Facilitate operation and maintenance of water services by local authorities }\end{array}$ \\
\hline $\begin{array}{l}\text { Facilitating com- } \\
\text { munity participation } \\
\text { and education }\end{array}$ & $\begin{array}{l}\text { Ensure implementation of effective community participation and education on all water services schemes } \\
\text { Ensure that training is targeted at local government level (e.g. water care operators) }\end{array}$ \\
\hline
\end{tabular}




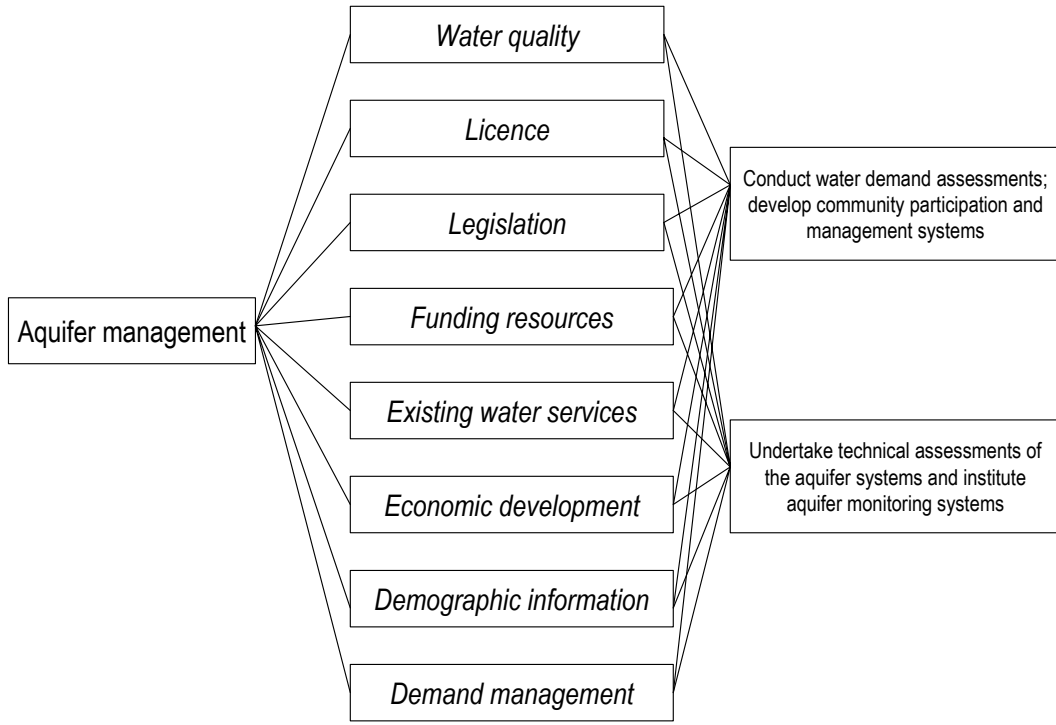

Figure 2

Value tree for aquifer management (Pietersen, 2004)

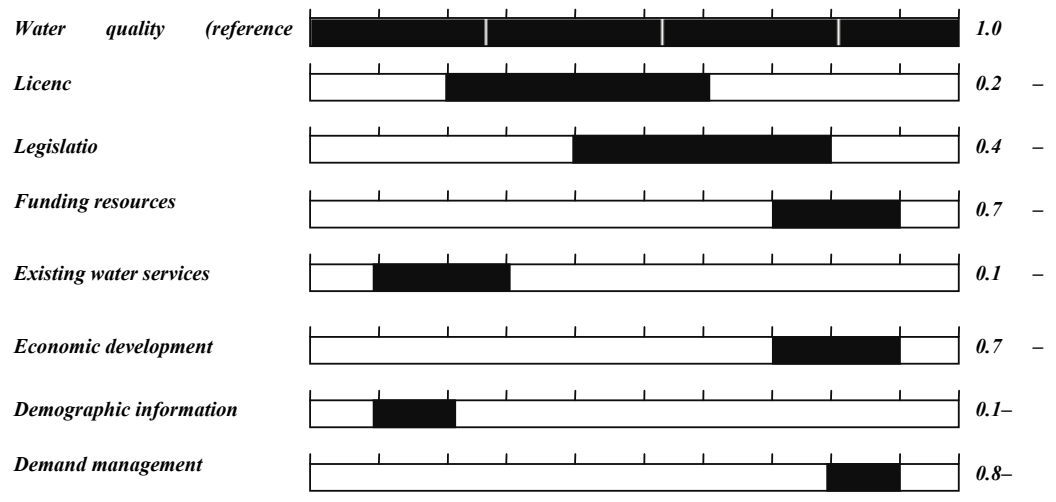

Figure 3

Interval SMART/SWING weighting in the decision-making procedure comparison of attributes (Pietersen, 2004)

Preference Programming (WINPRE) was used for the analysis. The following procedure was followed (after Mustajoki et al., 2004):

- Choose the most important attribute as reference attribute

- With respect to the reference attribute, compare the other attributes

- Assign 1.0 point to the best attribute

- Use preference ratios to calculate the values for the other attributes.

To illustrate the above process as an example, we used the objective and alternatives relating to aquifer management (Table 2). The attributes for proper aquifer management were chosen as (Pietersen, 2004):

- Proactive monitoring of drinking water quality with respect to:

- Substances which are general indicators of water quality

- Substances which are commonly present at concentrations which may lead to health problems

- Substances which occur less frequently at concentrations of real concern to health
- Substances which may commonly be present at concentrations of aesthetic or economic concern in domestic water sources (water quality)

- Licensing of all water uses (licence)

- Legislative requirements met, i.e. resource-directed measures and sourcedirected controls set. Institutions (catchment management agencies, water service providers, water service authorities) in place (legislation)

- Funds for capital and recurrent costs are available (funding resources)

- Technical data on existing water services incorporating detailed data on water sources, infrastructure, etc. available (existing water services)

- Water supplied for productive use and economic development (economic development)

- Macro-scale demographic information (growth, trends and dynamics) and community- based studies available (demographic information)

- Community-based demand-side planning takes place (demand management).

The problem is structured visually (Fig. 2). Figure 3 presents the interval SMART/ SWING weighting window of WINPRE. In this window a comparison is made between the attributes presented in the bulleted list above. In this case the reference attribute was chosen as drinking water quality. Access to clean water together with improved hygiene practices has a significant impact on human health in rural areas. The value intervals for the various attributes used to compare the two alternatives "community management" and "technical management" are reflected in Figs. 4 to 11 .

The value intervals (or constraints) for the attribute "water quality" are given in Fig. 4. Proper protection of the water resource from polluting activities will happen only happen if there is significant community management of the system. In arid zones, the natural quality of groundwater is poor, with trace constituents, such as fluoride in high concentrations. The system is also prone to microbial contamination as a result of improper protection measures. The value intervals (or constraints) for the attribute "licence" are given in Fig. 5. Transparent water allocation mechanisms are necessary to ensure proper allocation and thus the meeting of water demand adequately in space and time. The value intervals (or constraints) for the attribute "legislation" are given in Fig. 6. Legislation provides the framework for the setting up of, and establishes the level of, service to be provided. If a technical management approach is adopted, legislation will be implemented, more as a top-down approach lacking proper consultation, and institutions will be weak. Following a bottom-up community management approach will facilitate properly functioning institutions ideally supported by a sophisticated legislative framework. The value intervals (or constraints) for the attribute "funding resources" are given in Fig. 7. The available funding to a large degree influences 


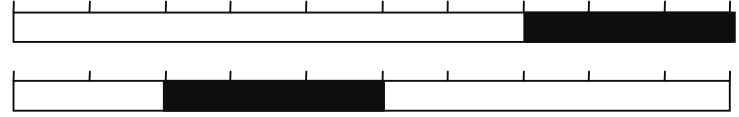

$0.7-1.0$

Technical management $0.2-0.5$

Figure 4

Local score intervals for attribute "water quality" (Pietersen, 2004)

Community management

Technical

management

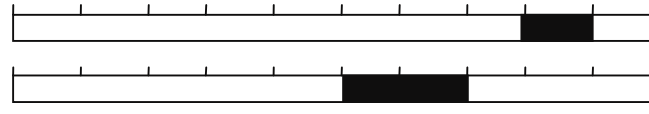

Figure 5

Local score intervals for attribute "licence" (Pietersen, 2004)

Community
management
Technical Technical
management management

Local score intervals for attribute "legislation" (Pietersen, 2004)

$$
\begin{aligned}
& \text { Community } \\
& \text { management } \\
& \text { Technical } \\
& \text { management }
\end{aligned}
$$

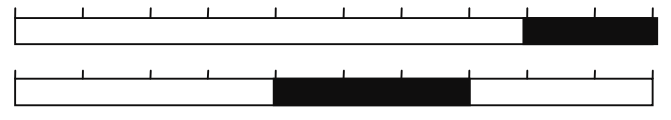

$0.8-1.0$

Figure 7

Local score intervals for attribute "funding resources" (Pietersen, 2004)

Community management

Technical management

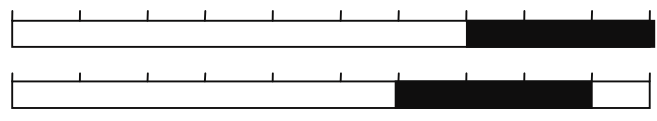

$0.7-1.0$

Figure 8

Local score intervals for attribute "existing water services" (Pietersen, 2004)

$\begin{aligned} & \text { Community } \\ & \text { management }\end{aligned}$
Technical
management

management

"economic development" (Pietersen, 2004)

Community management

Technical

management

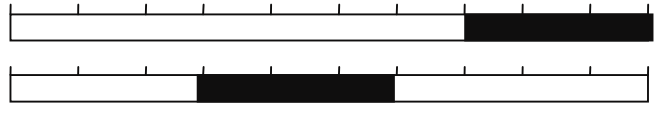

$0.7-1.0$ $0.3-0.6$

Figure 10

Local score intervals for attribute "demographic information" (Pietersen, 2004)

Community management

Technical

management

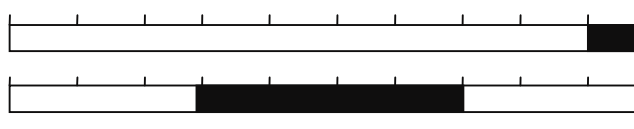

$0.9-1.0$

0.3

Figure 11

Local score intervals for attribute "demand management" (Pietersen, 2004)

the establishment and functioning of institutions and proper assessment of available groundwater resources. Adequate funding is required to meet the needs of the people suffering from a lack of resources. In most cases funding is controlled by technical parties as opposed to community management. The value intervals (or constraints) for the attribute "existing water services" are given in Fig. 8. The existing water services include aspects such as the level of service and which can determine water demand. Current focus of policy is on meeting the needs of un-serviced communities. The value intervals (or constraints) for the attribute "economic development" are given in Fig. 9.
The level of economic development will influence the level of services. This will be done in accordance with macro-economic policies in the affected region/country. The value intervals (or constraints) for the attribute "demographic information" are given in Fig. 10. Knowledge of population size, growth and dynamics is crucial for proper planning in terms of meeting water demand. Macro-scale demographic information is usually collected and verified, giving information on population growth, trends and dynamics. However, in addition to macro-scale information, community-based studies are being done to obtain community-scale demographic information. The value intervals (or constraints) for the attribute "demand management" are given in Fig. 11. Extreme climatic conditions such as drought pose many challenges for water demand in arid zones. There is competing demand for scarce water resources such as domestic use, livestock watering and for agricultural purposes. Proper demand planning means that communities' water requirements are likely to be met in an adequate manner.

The combination of the above relationships results in the overall value intervals and the dominance relations shown in Fig. 12. It is clear from the analyses that the alternative, "community management" which focuses on conducting water demand assessments and developing community participation and management systems, is the dominant alternative.

As a result, a number of value trees and attributes pertaining to alternative decisions (courses of action) were defined. These attributes were weighted and used to obtain insight into the relative desirability of the alternatives identified in Table 2 . This provided a systematic framework for the analytical understanding of the problem. A number of preferred alternatives were elicited (Pietersen, 2004). These are underlined and shown in italics in Table 2.

\section{Application of the decision model}

Figure 13 represents an idealised proposed approach and methodology for groundwater resource development and management in Namaqualand. This approach is based on work done by Titus et al. (2002) and Pietersen (2004) and is arrived at independently of MCDA. Application of this framework assumes that human and financial resources are readily available, which is hardly the case.

As a result of the application of an MCDA technique, a number of critical alternative courses of action and a decision- 
Figure 12

Overall value intervals and dominance relations (Pietersen, 2004)

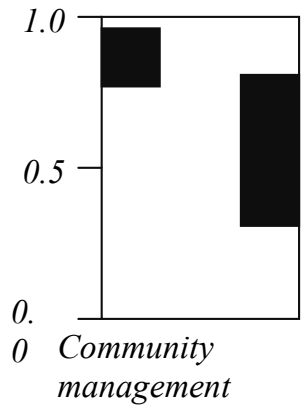

Technical

management

The alternative focusing on community management which includes conducting water demand assessments and developing community participation and management systems is the dominant alternative
Figure 13 Sequential steps for developing a water services strategy for rural groundwater supply in Namaqualand (Pietersen, 2004)

\begin{tabular}{|c|c|c|c|}
\hline Step 1 & Step 2 & Step 3 & Step 4 \\
\hline $\begin{array}{l}\text { Identify range of } \\
\text { appropriate technology } \\
\text { options }\end{array}$ & $\begin{array}{l}\text { Technical and } \\
\text { institutional assessment } \\
\text { of water services }\end{array}$ & $\begin{array}{l}\text { Present a range of } \\
\text { technical options to } \\
\text { communities }\end{array}$ & $\begin{array}{l}\text { Present implications for } \\
\text { community } \\
\text { management }\end{array}$ \\
\hline Step 8 & Step 7 & Step 6 & Step 5 \\
\hline $\begin{array}{l}\text { Facilitate democratic } \\
\text { decision -making } \\
\text { models } \\
\because \quad \because \quad \therefore\end{array}$ & $\begin{array}{l}\text { Community driven } \\
\text { water services } \\
\text { development plan }\end{array}$ & $\begin{array}{l}\text { Contractual agreements } \\
\text { between Authorities, Providers } \\
\text { and Customers }\end{array}$ & appropriate users in \\
\hline Step 9 & Step 10 & Step 11 & Step 12 \\
\hline $\begin{array}{l}\text { Re-assess existing } \\
\text { technical data }\end{array}$ & $\begin{array}{l}\text { Implement legislative } \\
\text { requirements }\end{array}$ & $\begin{array}{l}\text { Re-assess funding } \\
\text { commitments for capital } \\
\text { and recurrent costs }\end{array}$ & $\begin{array}{l}\text { Develop tanif structures } \\
\text { with the involvement of } \\
\text { appropriate usemers }\end{array}$ \\
\hline Step 16 & Step 15 & Step 14 & Step 13 \\
\hline $\begin{array}{l}\text { Detineate protectlon } \\
\text { zones } \\
\because \cdots\end{array}$ & $\begin{array}{l}\text { Regional groundwater } \\
\text { flow conceptuat modele } \\
\therefore \text { aquifer parameters }\end{array}$ & $\begin{array}{l}\text { Geological review } \\
\text { considering structural } \\
\text { aspects and geodynamics }\end{array}$ & $\begin{array}{l}\text { Pro-active monitoring } \\
\text { system for drinking } \\
\text { water quality }\end{array}$ \\
\hline Step 17 & Step 18 & Step 19 & \\
\hline $\begin{array}{l}\text { Artificial and water } \\
\text { harvesting systems } \\
\therefore \therefore \because \because \because \because \therefore\end{array}$ & $\begin{array}{l}\text { Water conservation and } \\
\text { demand management } \\
\because \because \because \because \because \because \because\end{array}$ & $\begin{array}{l}\text { Develop pro active } \\
\text { monitoring systems for } \\
\text { drought } \quad \therefore \quad \therefore\end{array}$ & $\begin{array}{l}\text { Implement water services } \\
\text { programme at community } \\
\text { level }\end{array}$ \\
\hline
\end{tabular}

making framework have been developed which otherwise would not have been elicited in a scientific manner (Pietersen, 2004). The routing, as described, of the objectives and alternatives identified by Pietersen (2004) through the value tree framework, enabled resulting attributes to be compared and evaluated and alternatives to be prioritised in terms of achieving the most desirable scenario linked to sustainable rural livelihoods. This enabled Pietersen (2004) to define a critical path for addressing groundwater management issues. The critical path focuses on the most crucial steps in the development of a rural groundwater supply strategy selected from a wide range of objectives, measures and the corresponding alternatives identified by Titus et al. (2002) and Pietersen (2004). The most important courses of actions resulting from the application of MCDA are those which are highlighted in Fig. 13. These need to be implemented in order to move more closely to the "ideal state". The decision model provides a more scientific foundation from which the critical path could be further rolled out and followed in practice, i.e. in order to identify and address the critical concerns of water resource managers. The process is not overly-complicated and does not absolve the decision maker from the necessary planning, judgement and management responsibilities (Pietersen, 2004).
As a result of the decision model a number of strategies are proposed for sustainable groundwater management in Namaqualand (Table 3). These strategies formed part of a larger set of potential strategies developed during the problem formulation stage and were arrived at during the identification of a critical path of issues to be addressed (Pietersen, 2004).

\section{Conclusion}

Prior to 1998, the use of groundwater was beyond the regulatory jurisdiction of the state. The National Water Act of 1998 corrected this situation and considers groundwater as an integral part of the hydrological cycle. The NWA provides the legal framework for groundwater management in South Africa, which will be put into practice through specific regulations.

The focus of groundwater management in South Africa, for the foreseeable future, will be on equitable allocation for economic development, maintaining resource integrity and meeting basic human needs. The challenge remains to implement these principles in reality. Management strategies will need to be developed to address the unique characteristics and roles of groundwater. This needs to take place within the 


\begin{tabular}{|c|c|}
\hline \multicolumn{2}{|r|}{$\begin{array}{c}\text { TABLE } 3 \\
\text { Groundwater management strategies for Namaqualand (Pietersen, 2004) }\end{array}$} \\
\hline Objective & Future direction \\
\hline $\begin{array}{l}\text { Involvement of } \\
\text { appropriate users in } \\
\text { technology selection }\end{array}$ & $\begin{array}{l}\text { Present a range of technical options to communities, which are affordable to operate and maintain. } \\
\text { If the technology is not affordable, as is the case in desalination, cross-subsidisation is inevitable, } \\
\text { e.g. through the use of the equitable share } \\
\text { Facilitate the involvement of women and children's participation in selecting the technology and } \\
\text { developing the cost-recovery system } \\
\text { - Use a participative technique for communities to choose the most appropriate system with a clear } \\
\text { understanding of their roles and responsibilities }\end{array}$ \\
\hline \multirow[t]{2}{*}{$\begin{array}{l}\text { Facilitate democratic } \\
\text { decision models }\end{array}$} & $\begin{array}{l}\text { - Acceptance by implementers that communities are the owners of water supply schemes } \\
\text { - Development of joint decision-making and trust should be developed among the various partners } \\
\text { - Identification of means of establishing community participation in the planning, design, implemen- } \\
\text { tation and O\&M of water services }\end{array}$ \\
\hline & - Fostering sound leadership in the community \\
\hline $\begin{array}{l}\text { Develop tariff struc- } \\
\text { tures with the involve- } \\
\text { ment of appropriate } \\
\text { users }\end{array}$ & $\begin{array}{l}\text { Provision of the outline and preliminary design of the actual design/maintenance programme, } \\
\text { including the requirements for training and cost recovery } \\
\text { Education of the community about the true cost of water, and early sourcing regarding the tariff } \\
\text { system }\end{array}$ \\
\hline \multirow{7}{*}{$\begin{array}{l}\text { Develop a regional } \\
\text { conceptual ground- } \\
\text { water flow model }\end{array}$} & $\begin{array}{l}\text { - Distinguish and potentially rate different aquifer systems, in terms of both yield and quality of } \\
\text { groundwater at a regional scale }\end{array}$ \\
\hline & $\begin{array}{l}\text { - Characterise the physical nature and understand as well as predict the variability in hydraulic } \\
\text { response of the aquifer system }\end{array}$ \\
\hline & $\begin{array}{l}\text { - Characterise the transmissivity and the available storage of the aquifer system based on the frac- } \\
\text { tured nature of aquifers and the available drawdown that is associated with the thickness of the } \\
\text { regolith (i.e. weathered overburden), the depth to the most productive fracture zone(s) and the depth } \\
\text { to the water table and/or piezometric level }\end{array}$ \\
\hline & $\begin{array}{l}\text { - Develop a regional groundwater flow model for a particular aquifer system with due reference to the } \\
\text { tectonic and geomorphic development for the basement aquifer systems. The regional groundwater } \\
\text { flow, for a particular aquifer system, must be based on the hydraulic gradients (as a function of } \\
\text { elevation differences) and the average depth at which water could be sampled }\end{array}$ \\
\hline & $\begin{array}{l}\text { - Describe and distinguish between the various flow systems, for a particular aquifer system, at the } \\
\text { relevant scale }\end{array}$ \\
\hline & $\begin{array}{l}\text { - Characterise the processes (i.e. water rock interaction, residence, evapotranspiration, etc.) that result } \\
\text { in the generally poor groundwater quality and take cognizance of the factors (i.e. complex ground- } \\
\text { water flow paths and flow systems, differential weathering processes, spatial variation in rainfall, } \\
\text { etc.) that result in spatial and temporal variations in the groundwater chemistry for a specific aquifer } \\
\text { system }\end{array}$ \\
\hline & $\begin{array}{l}\text { - Describe the seasonal and long-term climatic variability and the effects on both the quantity and } \\
\text { quality of groundwater for a specific aquifer system }\end{array}$ \\
\hline \multirow{5}{*}{$\begin{array}{l}\text { Select the most } \\
\text { favourable target(s) for } \\
\text { development (target } \\
\text { selection should be } \\
\text { based on a combination } \\
\text { of favourable factors) }\end{array}$} & $\begin{array}{l}\text { - Apply appropriate geophysical technologies and interpret results based on the conceptual under- } \\
\text { standing of the aquifer system }\end{array}$ \\
\hline & $\begin{array}{l}\text { - Conduct exploratory drilling and re-define knowledge and conceptual models on aquifer systems at } \\
\text { this particular scale }\end{array}$ \\
\hline & $\begin{array}{l}\text { - Undertake borehole development which must include the drilling of monitoring boreholes for the } \\
\text { calculation of hydraulic parameters (i.e. storativity). The relative positioning (i.e. hydraulic con- } \\
\text { nectivity and hydraulic system) and optimal number of boreholes and depth and of boreholes are } \\
\text { important factors }\end{array}$ \\
\hline & $\begin{array}{l}\text { - Select the appropriate numerical method(s) for test pumping analyses based on the meeting of } \\
\text { underlying conditions for the particular method(s) and on a conceptual understanding of the aquifer } \\
\text { system. Data collection in the field must be as accurate and representative as possible }\end{array}$ \\
\hline & $\begin{array}{l}\text { - Determine the sustainable yield of the aquifer system with due consideration of all the above-men- } \\
\text { tioned factors. Select an appropriate approach for a particular region and utilise relevant techniques }\end{array}$ \\
\hline $\begin{array}{l}\text { Delineate protection } \\
\text { zones }\end{array}$ & $\begin{array}{l}\text { - Application of measures to protect the aquifers from threats (i.e. use of techniques for delineating } \\
\text { protection zones in fractured environments) }\end{array}$ \\
\hline
\end{tabular}




\begin{tabular}{|c|c|}
\hline \multirow{5}{*}{$\begin{array}{l}\text { Artificial recharge } \\
\text { and water harvesting } \\
\text { systems }\end{array}$} & $\begin{array}{l}\text { - Implement artificial recharge schemes to supplement poorly naturally recharged groundwater sys- } \\
\text { tems when surface water resources are in excess }\end{array}$ \\
\hline & - Continue conjunctive water use of groundwater and surface water resources \\
\hline & $\begin{array}{l}\text { - Implement water harvesting in rainfall tanks and the construction of structures to channel overland } \\
\text { flow to reservoirs }\end{array}$ \\
\hline & - Consider fog harvesting in coastal and mountainous regions \\
\hline & $\begin{array}{l}\text { - Implement water harvesting during exceptional rainfall events through retention walls in streams to } \\
\text { enhance infiltration }\end{array}$ \\
\hline Drought prediction & - Predict drought conditions using most appropriate means \\
\hline
\end{tabular}

context of the socio-economic development paradigm.

Through applying the decision model described in this paper a number of strategies have been proposed for sustainable groundwater management in Namaqualand. This approach can be extended to similar environments in South Africa. These strategies form part of a larger set of potential strategies developed during the problem formulation stage and narrowed down during the identification of the critical path of issues to be addressed. The strategies are aligned closely with the legislative requirements of the NWA. Thus, MCDA has been utilised to develop policy responses and strategies for groundwater management at community and catchment scale, based on the NWA.

It has been demonstrated that the application of MCDA is an innovative planning and information technology tool to assist the decision-making process towards sustainable groundwater resource management. The application of the tool in a participatory environment requires further refinement and adaptation (including further work related to sensitivity analysis). However, MCDA is a tool and should be viewed as such by water resource managers. This means that methodology should be used circumspectly by decision makers with the necessary experience base. A "black box" approach should be cautioned against.

\section{Acknowledgements}

The author would like to thank the Water Research Commission for the financial contribution to conduct the research. Dr. GC Green is thanked for his critical review of this work.

\section{References}

ADAMS S, TITUS R and XU Y (2004) Groundwater Recharge Assessment of the Basement Aquifers of Central Namaqualand. WRC Report No. 1093/1/04. Water Research Commission, Pretoria. ISBN 1-77005-214-3.

ALLEY WM and LEAKE SA (2004) The journey from safe yield to sustainability. Ground Water 42 (1) 12-16.

BELTON V and STEWART TJ (2002) Multiple Criteria Decision Analysis - An Integrated Approach. Boston/Dordrecht/London: Kluwer Academic Publishers.

BRAUNE E (2003) Groundwater perspective on integrated water resource management - Recharge, a critical indicator of sustainability. In: Xu Y and Beekman HE (eds.) Groundwater Recharge Estimation in Southern Africa. UNESCO IHP Series No. 64, UNESCO Paris. ISBN 92-9220-000-3.

DE MONTIS A, DE TORO P, DROSTE-FRANKE B, OMANN I and STAGL S (2000) Criteria for quality assessment of MCDA methods. Proc. $3^{\text {rd }}$ Bienn. Conf. Eur. Soc. Ecol. Econ. Vienna. May 3-6, 2000.

DIETRICH J and HÄMÄLÄINEN RP (2002) Value Tree Analysis - Working Draft 16.04.02. Helsinki University of Technology,
Systems Analysis Laboratory. [Online]. Available http://www.sal. hut.fi/Publications (accessed in 2004).

DWAF (1997) Water Services Act. Government Gazette of the Republic of South Africa. 390 (18522), 19 December 1997.

DWAF (1998) National Water Act. Government Gazette of the Republic of South Africa. 398 (19182) 26 August 1998.

FAO (2003) Groundwater Management - The Search for Practical Applications. Water Reports 25. Food and Agriculture Organization of the United Nations. ISBN 92-5-104908-4

FRIESE AEW, SWARTZ HG, TITUS R, FIELIES A, DAVIDS S and DOMONEY R (2005) Geomechanical Modelling as a Tool for Groundwater Exploration of Fractured Rock Aquifers in the Namaqualand Region, South Africa. WRC Report No. 1117/1/05. Water Research Commission, Pretoria.

HAJKOWICZ S, YOUNG M, WHEELER S, McDONALD DH and YOUNG D (2000) Supporting decisions: Understanding natural resource management assessment techniques. CSIRO Land and Water. [Online]. Available http://www.clw.csiro.au/publications consultancy/2000/support decisions.pdf (accessed on 16 January 2006).

HÄMÄLÄINEN RP and MÄNTYSAARI J (2001) A dynamic interval goal programming approach to the regulation of a lake-river system. J. Mult-Crit. Decis. Anal. 10 75-86.

KALF FRP and WOOLLEY DR (2005) Applicability aned methodology of determining sustainable yield in groundwater systems. Hydrogeol. J. 13 (1) 295-312.

LINDSTEDT MRK, HÄMÄLÄINEN RP and MUSTAJOKI J (2000) Using intervals for global sensitivity analyses in multi-attribute value trees. Proc. $15^{\text {th }}$ Int. Conf. on Multiple Criteria Decision Making. Ankara, Turkey, July 10-14. In: Murat Köksalan and Stanley Zionts (eds.) Lecture Notes in Economics and Mathematical Systems. (2001) $\mathbf{5 0 7}$ 177-186.

MAIMONE M (2004) Defining and managing sustainable yield. Ground Water 42 (6) 809-814,

MORRIS BL, LAWRENCE ARL, CHILTON PJC, ADAMS B, CALOW RC and KLINCK BA (2003) Groundwater and its Susceptibility to Degradation: A Global Assessment of the Problem and Options for Management. Early Warning and Assessment report series, RS. 03-3. United Nations Environment Programme, Nairobi, Kenya.

MUSTAJOKI J and HÄMÄLÄINEN RP (1999) Web-HIPRE - Global decision support by value tree and AHP analysis. [Online] Available http://www.sal.hut.fi/Publications/pdf-files/mmus99.pdf (accessed on 16 January 2006).

MUSTAJOKI J, HÄMÄLÄINEN RP and SALO A (2004) Decision support by interval SMART/SWING - Incorporating imprecision into SMART and SWING (Manuscript January 16, 2004). Available [Online] http://www.sal.hut.fi/ Publications/pdf-files/mmus. pdf (accessed on 16 January 2006).

ODENDAAL FJ (2001) Incremental value of poverty alleviation funding for sustainable development - a case study from Namaqualand, South Africa. [Online]. Available http://:www.dlist.org/docs/ PA paper FJO 2204 FINAL.doc. (accessed on 16 January 2006).

PIETERSEN KC (2004) A Decision-Making Framework for Groundwater Management in Arid Zones (with a Case Study in Namaqualand). Unpublished Ph.D. thesis, University of the Western Cape 
PÖYHÖNENM and HÄMÄLÄINEN RP (2001) On the convergence of multi-attribute weighting methods. Eur. J. Oper. Res. 19 569-585.

TECLE A and DUCKSTEIN L (1994) Concepts of multicriterion decision making. In: Bogardi JJ and Nachtnebel HP (eds.) Multicriteria Analysis in Water Resources Management. UNESCO, Paris: 33-62.

TITUS R, PIETERSEN K, WILLIAMS M, ADAMS S, XU Y, SAAYMAN I and COLVIN C (2002) Groundwater Assessment and Strategies for Sustainable Resource Supply in Arid Zones - The
Namaqualand Case Study. WRC Report 721/1/02. Water Research Commission, Pretoria.

YOUNGE A (2002) IDP assessment - Namakwa District. [Online]. Available http//:www.dlist.org/docs/ Namakwa IDP Assessment 2002 Final_Report_pdf (accessed on 16 January 2006).

XU Y, BRAUNE E, COLVIN C, LE MAITRE D, PIETERSEN K and HATTON T (2000) Comprehensive determination of the resource directed measures for groundwater in South Africa. In: Sililo et al. 